DOI: $10.18276 / \operatorname{sip} .2018 .51 / 3-20$

\author{
Kamila Radlińska*, Maria Klonowska-Matynia** \\ Politechnika Koszalińska \\ Wydział Nauk Ekonomicznych
}

\title{
SEASONALITY OF THE TOTAL NUMBER OF THE WORKERS IN POLAND ${ }^{1}$
}

\begin{abstract}
Seasonality is an issue discussed relatively rarely in the labor market analyses. More frequent research in the area of labor market focuses on a long-term or cyclical analysis, but seasonal fluctuations may constitute a significant part of the short-term variability of phenomena. Full labor market analysis requires the consideration of short-term changes as well. This paper aims at the analysis of seasonality of the total number of the workers in Poland. Within the framework of the analysis one attempted to define the size and tendency of changes in seasonality of the number of the workers in Poland and its distribution in the course of the year. The analysis was based on the Central Statistical Office data on the number of the workers in Poland from January 2010 to December 2017. Seasonal factors of the number of the workers were separated with the Census X-12 ARIMA algorithm. The obtained results indicate that the seasonality of number of workers in Poland is small, it is characterized by a falling tendency.
\end{abstract}

Keywords: labor market, workers, seasonality

* E-mail: kamila.radlinska@tu.koszalin.pl

** E-mail: maria.klonowska-matynia@tu.koszalin.pl

1 This paper has been financed by the National Science Centre pursuant to the decision DEC-2013/09/B/HS4/00488 


\section{Introduction}

Contemporary labor market is determined by changes arising from globalisation, progressive servitisation of economy, increasing competitiveness, fast development of technology, change in lifestyle, or ageing society. Impact of these phenomena makes the labor market unstable and permanently characterised with uncertainty. That is why the labor market monitoring is so important, just like searching for new solutions in a fight with incomplete use of resources and preventing the occurrence of negative phenomena on the labor market. Cognition of the reasons of the labor market's instability constitutes an important (from the scientific point of view) cognitive value and the basis to create an efficient state policy. Issues of the labor market are frequently discussed in the economic Polish and foreign literature. The discussed areas include the issue of unemployment, incomplete use of the labor resource in economy, spatial diversity of unemployment and employment, professional activity, seasonality of employment, temporary job (Hall, 1991, p. 27; Lopes de Melo, 2018, p. 321; Olkiewicz, 2015, p. 401; Rembeza, Radlińska, Klonowska-Matynia 2015, p. 360). It results from the fact that the labor market issues have one of the severest economic and social consequences. Changes in basic indicators characterising the labor market are derivatives from changes occurring in the entire national economy (Aoyama, Castells, 2002, p. 141). The relation between the economic situation and the employment is one of the most frequently discussed issues. This state of affairs may result from an observation that in the majority of the developed and developing countries there is noticed a chronic issue of the failure to use the labor resource.

Changes in the level of activity of the labor resource constitute one of the directions of potential labor market analyses. These changes may be considered in a long period, cyclically or seasonally. The closest attention is paid to the long-term and cyclical changes, while seasonal changes may constitute an important component of the labor market's description. The occurrence of seasonal fluctuations on the labor market has generally an adverse impact on the entire economy, causing deviations from the rhythmic course of business processes.

The condition of the research concerning changes in the level of the labor resource's activity, particularly in the area of seasonal changes, still seems to be insufficient. That is why an analysis towards it has been conducted. This paper aims at the analysis of seasonality of the number of the workers in Poland from 2010 to 2017. It 
is attempted to determine the size and tendency of changes in the seasonality of number of the workers and their distribution during the year. The study uses the monthly data on the number of the workers for Poland. The analysis period concerned from the January of 2010 to the December of 2017. The data comes from the Central Statistical Office in Poland. A Census X-12 procedure based on seasonal ARIMA models was used to decompose the seasonal factors.

\section{Employment and workers on labor market in Poland}

Dynamics of changes on the labor market may be described with various values. Employment is one of the most popular values. The employed persons in the national economy in Poland are those hired based on the employment contract for a definite and indefinite period of time, on a full-time and part-time basis, wage workers on individual farms, as well as teachers retired or on sick leaves (GUS, 2018). The Labor Code (Ustawa, 1974) specifies that by entering into the work relationship the employee undertakes to perform work of a defined type for the benefit of the employer and under its supervision, in place and at time determined by the employer, while the employer undertakes to hire the employee against remuneration. Therefore, employment is a payable commitment of human labor in business activity based on an agreement between the employer and the employee. Full employment, which is difficult to be achieved in all economies, is a desired phenomenon on a scale of entire economy. Authors of the labor market research look for the reasons of instability in the application of deactivating forms of social security of the unemployed. Other research refers to the low level of education of the jobseekers (Biddle, 2014, p. 202; Pissarides, 1991, p. 23), too high labor costs (Blanchard, Landier, 2002, p. 7) or low quality of job placement. In Poland, institutional changes in the labor market started with the Act on the promotion of employment and labor market institutions. It resulted in a change in the state employment service's organisation. Currently, the Polish labor law does not deteriorate a situation on the labor market. Employers have at their disposal a broad range of employment forms and apply them according to their needs.

In the Polish statistics (GUS, 2018), there is the category of the employed persons and of the workers. The workers are people performing work that brings them income or profit. They include persons hired based on the employment contract or 
labor-based relationship, employers and self-employers (owners, co-owners and lessees of individual farms, owners and co-owners, entities running business activity apart from individual farms, other self-employers, e.g. freelancers), outworkers, agents, members of agricultural cooperatives, and priests performing pastoral duties. This category does not include the number of the workers in budgetary units operating within the scope of national defence and public safety. The Polish Classification of Activity (PKD 2007) is one of the presentations of data on the number of the workers. The workers are classified under particular sections and departments by appropriate qualification of particular enterprises based on their identification numbers in the REGON system. Data by the PKD 2007 sections within the scope of the workers concern business entities of the enterprise sector hiring more than nine workers. Both categories describe the labor resource's activity.

\section{Data and method}

Determination of the level of seasonality of the number of the workers in Poland from 2010 to 2017 and seasonality of the number of the workers in the course of the year constituted the main research purpose.

The analysis was based on the data on a monthly number of the workers according to the status as of the end of a month (GUS, 2018). Research on the seasonality of the workers was conducted for the period from January 2010 to December 2017. 2010 was the first year for which the Central Statistical Office had its statistics concerning a monthly number of the workers. 2017 was the last full reporting year.

Data on the number of the workers collected in that way were analysed with regard to seasonality. There is a range of methods and procedures to decompose time series, the main purpose of which is the clearance of time series from seasonal fluctuations (Fischer, 1995, p. 2; Grudkowska, Paśnicka, 2007, p. 34; Makridakis et al., 1982).

Seasonality is a regularly repeating dependency among the observations distant from each other by a constant number of periods. In the event of economic phenomena it is usually considered within the calendar year. Separation of seasonality allows for the comparison and interpretation of changes in a phenomenon period by period, showing phenomena reflecting changes in economy not resulting from purely seaso- 
nal and calendar factors. Moreover, it allows for the determination of the specificity of a country or a region.

Separation of a seasonal component consists in the decomposition from a time series of a seasonal component $(\mathrm{St})$, trend component $(\mathrm{Tt})$, cyclical component $(\mathrm{Ct})$ and random component - error (It) and assumes the following form:

$$
X t=T t \square S t \square I t \square E t \backsim D t
$$

Functional dependency among the components may assume two forms, additive or multiplicative. In the research the multiplicative model is applied. In this paper one applies the X-12 ARIMA procedure.

Based on the seasonally refined data, the average annual seasonal fluctuations in the number of the workers in particular years in Poland and the average monthly fluctuations in the number of the workers in particular months were calculated.

This paper aims at the analysis of seasonality of the total number of the workers in Poland. Having regard to the main purpose of the paper, the research procedure scheme was planned, including the following stages:

Stage 1: Characteristics of the total number of the workers in Poland.

Stage 2: Analysis of seasonality of the total number of the workers in Poland from 2010 to 2017 and in the course of the year.

\section{Results}

An initial stage of the research was the characteristics of the total number of the workers in Poland from 2010 to 2017. To illustrate the tendency in the number of the workers, one applied the aggregated monthly data on the number of the workers in Poland in business entities from the enterprise sector hiring more than nine workers. While describing the total number of the workers in Poland from 2010 to 2017 , there can be noticed a long-term upward trend of the total number of the workers. In the first two years of the analysis (2010-2012), there is noticed a significant increase in the number of the workers. The 2012-2017 period is characterised with less dynamic changes in the number of the workers (Fig. 1). 
Figure 1. Total number of the workers in Poland from 2010 to 2017

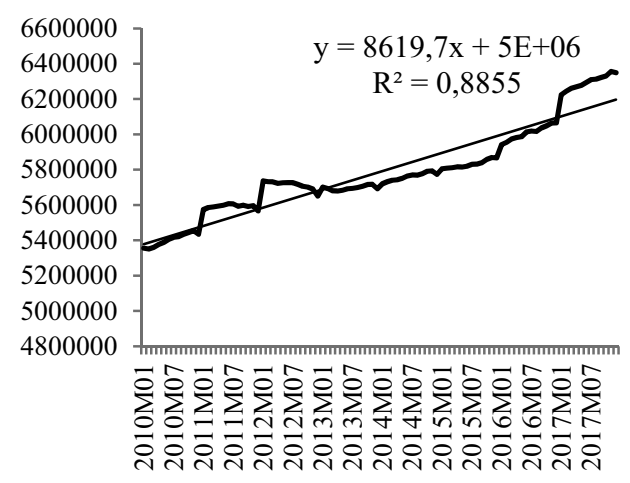

Source: own elaboration on GUS data.

A significant element of an analysis of a tendency of the total workers number is the diversity of the number of the employed in particular sections of PKD 2007. Characteristics can be conducted based on the groups of the workers proposed by the Central Statistical Office by the section. The Central Statistical Office aggregates the workers in sections that, according to the methodology of the CSO, jointly constitute the workers' category in Poland.

While analysing the monthly information on the number of the workers in the whole researched period, there can be separated the periods when regular consecutive increase and decrease in the number of the workers occurred, thus indicating the occurrence of the phenomenon of seasonality of the number of the workers. It may be connected with the occurrence of economic sectors exposed to the fluctuations in seasonality in the number of the workers. An analysis of seasonality of the number of the workers constituted another stage of the research.

The seasonality analysis was based on seasonal factors of the number of the workers, which were separated with the Census X-12 ARIMA algorithm. Results of the research on seasonality of the number of the workers indicate that the average seasonality of the number of the workers in Poland is low (Fig. 2). In the whole researched period, a long-term negative tendency of the seasonality indicator is noticed. In 2010, the average annual indicator of seasonality of the total number of the workers in Poland came to $0.36 \%$ and decreased to $0.28 \%$ in 2017 . Relatively low 
Figure 2. Average monthly fluctuation in seasonality of the workers in Poland from 2010 to 2017

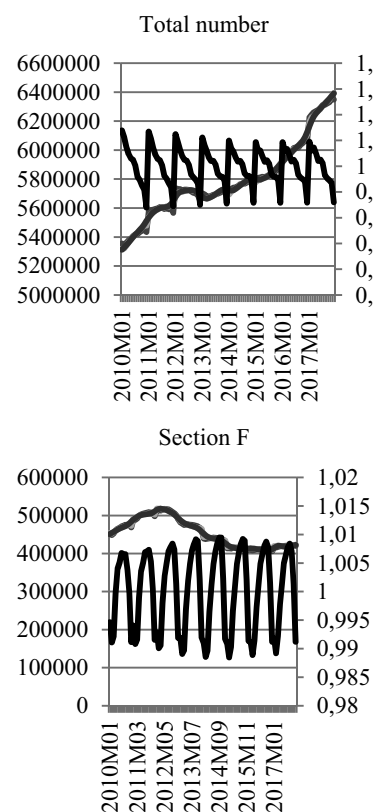

Section L

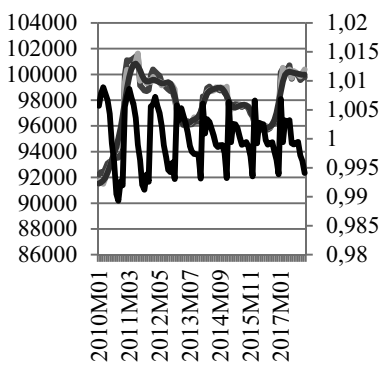

Section B, C, D, E

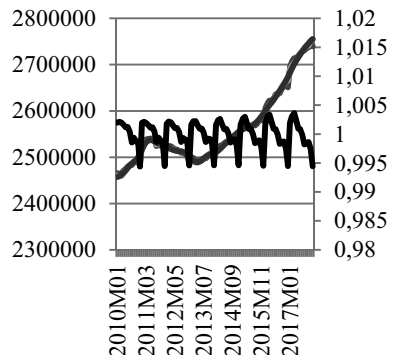

Section G

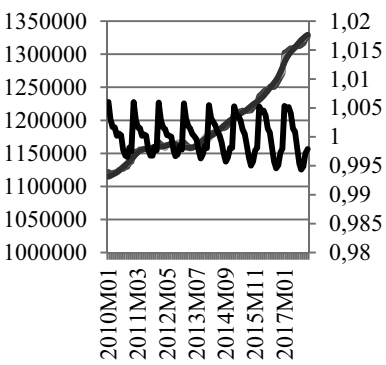

Section M

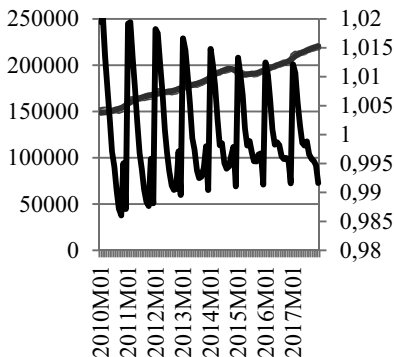

Section C

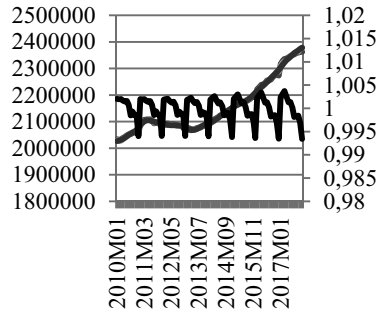

Section I

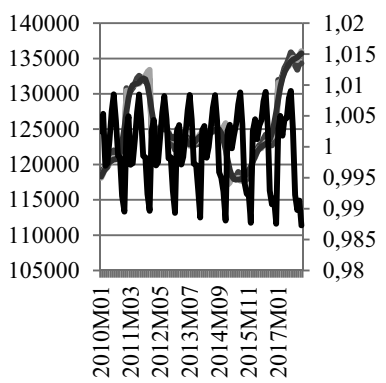

Section $N$

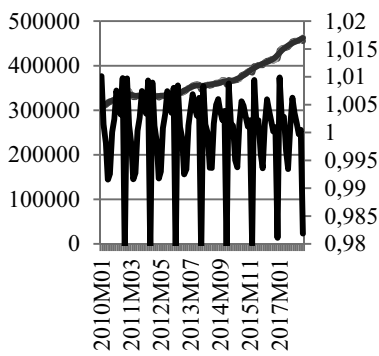

$\begin{array}{lll}\text { Total number of workers in each section } & \text { Seasonal adjusted } \\ \text { Trend-Cycle } & \text { Seasonality factors }\end{array}$

Source: own elaboration on GUS data.

indicators of seasonality of the number of the workers may be connected with the diversity of seasonality of the number of the workers in particular sections.

An analysis of diversity of the seasonality indicators in sectors indicated that, in principle, indicators of the average annual seasonality of the number of the workers 
in all economy sectors increased. Only in the three sections: real estate activities, professional, scientific and technical activities and administrative and support service activities, the indicators of seasonality of the number of the workers decreased.

The course of seasonality throughout the year also seems to be interesting. The next step of the research was the analysis of the distribution of monthly seasonal fluctuations of the number of the workers in the course of the year. In the analysed period two periods occurred. The first period - from January to August - is a period in which seasonality indicators for the number of the workers are positive, while in the second period - from August to December - the indicators are negative. This observation requires the deepened analysis of indicators of the seasonal number of the workers in particular sections.

Seasonality of the number of the workers in the first seven months of a year is positive - the seasonal workers appear on the labor market. The highest levels of seasonality of the number of the workers are observed in the first four months of a year. From August to December the number of the seasonal workers is decreasing. The highest decrease in the number of the seasonal workers is observed in December. August, September, October and November do not differ significantly with each other with regard to the seasonality of the number of the workers. Such a situation may result from the cycle of hiring employees and macroeconomic conditionings, however, this regularity requires a closer analysis.

Figure 3. Seasonal fluctuations in the number of the workers in Poland from 2010 to 2017 in the course of the year

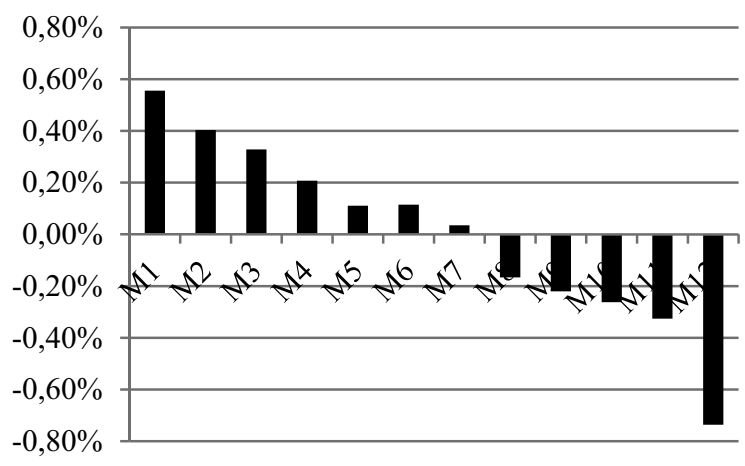

Source: own elaboration on GUS data. 
The research of seasonality of the total number of the workers has allowed for the following observations:

1. Seasonal fluctuations in the total number of the workers in Poland from 2010 to 2017 are relatively small and characterised with a long-term downward trend.

2. Seasonality of the total number of the workers in the course of a year is characterised with a positive level from January to July and a negative level from August to December.

A limitation for the conducted analyses was mainly the aggregation of data on the number of the workers collected by the Central Statistical Office. For the analysis of seasonality of the number of the workers the data aggregated in smaller spatial units, e.g. in voivodeships, poviats, would be more useful. Due to these limitations, the research conducted within the framework of this paper constitutes only an introduction to subsequent analyses and shall be the subject of considerations in the authors' further research.

\section{Conclusion}

The presented analyses of the labor resource's activity in Poland from 2010 to 2017 allow for the two group of conclusions. The first one concerns changes in the total number of the workers in Poland, while the second one - assessment of seasonal fluctuations in the number of the workers.

The conducted observation confirms that the total number of the workers in economy has been changing in time. Moreover, it has allowed for the statement of its upward trend, which should be assessed positively. In the first two years of the analysis there occurred a significant increase in the number of the workers, while in the subsequent three years that increase was maintained, but less intensive. The presented data on the number of the workers allow also for the statement that in the course of the year there occur the periods of increase and then decrease in the number of the workers. The conclusion from the analysis of seasonality of the number of the workers in Poland is that seasonal fluctuations in the total number of the workers are relatively small. It may be related to the use of the aggregated data on the number of the workers. Moreover, seasonality of the total number of the workers in the economy in the course of the year is characterised with a positive level from 
January to July and a negative value from August to December. Assessment of the strength of fluctuations in the course of the year allows for the observation that the highest increase in the seasonal workers occurs in January, while the lowest - in December. It may result from the employment policy of enterprises or structure of business sections.

\section{References}

Aoyama, Y., Castells, M. (2002). An Empirical Assessment of the Informational Society: Employment and Occupation Structures of G-7 Countries 1920-2000. International Labor Review, 1-2 (141), 123-159.

Biddle, J.E. (2014). Retrospectives: the cyclical behavior of labor productivity and the emergence of the labor hoarding concept. Journal of Economic Perspectives, 2 (28), 197-212. Biddle, J.E. (2015). The Genealogy of the Labor Hoarding Concept. In: L. Fiorito , S. Scheall, C.E. Suprinyak (ed.), A Research Annual (Research in the History of Economic Thought and Methodology, 33) (pp. 125-161). Emerald Group Publishing Limited.

Blanchard, O. (2004). Designing labor market institutions. Memo. Cambridge: MIT and NBER.

Blanchard, O., Landier, A. (2002). The perverse effects of partial labour market reform: fixed-term contracts in France. The Economic Journal, 112 (480), 214-244.

Fischer, B. (1995). Decomposition of Time Series: Comparing Different Methods in Theory and Practice. Version 2.1. Luxemburg: Eurostat March/April.

Grudkowska, S., Paśnicka, E. (2007). X-12 ARIMA i TRAMO/SEATS - empiryczne porównanie metod wyrównania sezonowego w kontekście dlugości próby. Warszawa: Narodowy Bank Polski.

GUS (2018). Retrieved from: www.bdl.stat.gov.pl (31.03.2018).

Hall, R.E. (1991). Demand, Labor Supply, and .Employment Volatility. NBER Macroeconomics Annual 1991, 6, 17-62.

Lopes de Melo, R. (2018). Firm Wage Differentials and Labor Market Sorting: Reconciling Theory and Evidence. Journal of Political Economy, 1 (126), 313-346.

Makridakis, S. et al. (1982). The accuracy of extrapolation (time series) methods: Results of a forecasting competition. Journal of Forecasting, 1 (2), 111-153.

Olkiewicz, M. (2015). Knowledge management as a determinant of innovation in enterprises. Bucharest: Proceedings of The ${ }^{\text {th }}$ International Management Conference Management and Innovation For Competitive Advantage. 
Pissarides, Ch.A. (1991). Labor Hoarding in Industrial Countries: Concept and Measurement. Paris: Eurostat, ISTAT and OECD.

Rembeza, J., Klonowska-Matynia, M., Radlińska, K. (2015) Regionalne zróżnicowanie sezonowości bezrobocia w Polsce, Niemczech i Hiszpanii. Studia Prawno-Ekonomiczne, 94, 367-379.

Ustawa (1974). Ustawa z dnia 26 czerwca 1974 r. - Kodeks pracy. DzU 1974, nr 24, poz. 141.

\section{SEZONOWOŚĆ OGÓLNEJ LICZBY PRACUJĄCYCH W POLSCE}

\section{Streszczenie}

Sezonowość jest problemem podejmowanym w analizach rynku pracy relatywnie rzadko. Prowadzone badania koncentrują się na długookresowej lub cyklicznej analizie kategorii rynku pracy, pomijając fakt, że odchylenia sezonowe mogą stanowić istotną część krótkookresowej ich zmienności. Pełna analiza rynku pracy wymaga uwzględnienia także zmian o charakterze krótkookresowym. Celem artykułu jest analiza sezonowości ogólnej liczby pracujących w Polsce. W ramach analizy starano się określić wielkość oraz tendencję zmian sezonowości liczby pracujących w Polsce oraz jej rozkład w trakcie roku. Podstawą analizy były dane o liczbie pracujących w Polsce w okresie od stycznia 2010 do grudnia 2017 roku pochodzące z Głównego Urzędu Statystycznego. Sezonowe składniki liczby pracujących wyodrębniono algorytmem Census X-12 ARIMA.

Słowa kluczowe: rynek pracy, pracujący, sezonowość

Kody JEL: C1, E23, E32, J21 